\title{
The Camp of the Tenth Legion at Jerusalem and the City of Ælia
}

\section{W. Wilson}

To cite this article: C. W. Wilson (1905) The Camp of the Tenth Legion at Jerusalem and the City of Ælia, Palestine Exploration Quarterly, 37:2, 138-144, DOI: 10.1179/peq.1905.37.2.138

To link to this article: http://dx.doi.org/10.1179/peq.1905.37.2.138

巴nublished online: 20 Nov 2013.

Submit your article to this journal $\longleftarrow$

ЏII Article views: 7

Q View related articles $\square$ 


\section{THE CAMP OF THE TENTH LEGION•AT JERUSALEM AND THE CITY OF ELIA.}

By Major-General Sir C. W. WiLson, K.C.B., K.C.M.G., LL.D., \&c.

1. The Walls of the Roman Camp, A.D. 70-132.-Jerusalem, after its capture by the Romans, became a Legionary fortress, or permanent "Camp"; and it so remained until the revolt of the Jews in the reign of Hadrian (A.D. 132). No record of the size of the "Camp" has been preserved; no tradition exists with regard to its position; and no trace of its limits has yet been found.

Titus, when ordering the demolition of the fortifications of the city, decided to spare the west wall of the "Upper City" that it might serve as a barrack for his troops; and the three towers, Phasaelus, Hippicus, and Mariamne, that they might show future generations how strong the defences of Jerusalem had been. The troops left by Titus as a garrison consisted of the Tenth Legion, Fretensis, with certain auxiliaries-troops of horsemen, and companies of footmen. ${ }^{1}$ From the above it may be inferred that the north-west angle of the "Camp" was near the Jaffa Gate, where the fortified palace of Herod and the three towers stood. Unfortunately nothing is known of the steps which the Roman engineers took to convert Jerusalem into a Legionary fortress. The circumstances were so exceptional that they may have abandoned their normal arrangements. On the other hand, it seems most probable that they carried out their work in accordance with the general principles governing the construction of fortified camps, and that, wherever it was practicable, they utilised the existing fortifications.

The "Upper City" was defended on its north, west, and south sides by the first wall, and on its east side by a wall that ran along the low cliff on the right bank of the Tyropoeon Valley. This wall is not mentioned by Josephus, ${ }^{2}$ but its existence may be inferred from

1 B.J., vii, 1, §§ 1, 2. The legion, or the bulk of it, was doubtless quartered at Jerusalem; the auxiliaries may have garrisoned smaller forts at important points in Judæa.

2 This is not remarkable, for Josephus, in his description of the walls, never alludes to the great peribolos wall of the Temple precincts which still attracts the wonder and admiration of travellers. The fragments of masonry referred to by Schick (Quarterly Statement, 1898, pp. 81, 82) may hare belonged to the wall. 
the fact that the "Upper City" was able to hold out after the Temple and the "Lower City" were in the hands of the Romans. Titus was obliged to undertake regular siege operations before he could force an entrance. ${ }^{1}$ When at last the "Upper City" fell, its fortifications, with the exception of a breach in the west wall, were intact. ${ }^{2}$

It may be regarded as almost certain that for the north and west walls of the "Camp" the engineers utilised portions of the first or old wall, but the trace adopted for the east and south walls is not so clearly indicated. A Legionary fortress was, as a rule, a square or oblong, with rounded angles, and about 50 acres in extent. Thus Caerleon is 51 acres, York probably 48, Chester probably 53, Lambasis 52, and Bonn 61 ; the proportion of length to breadth varies in each case. ${ }^{3}$ The "Camp" at Jerusalem may not have been of the usual form, but, if the bulk of the Legion was quartered there, its area would be normal, and, in attempting to locate it, a space of about 50 acres must be allowed. The ground enclosed by

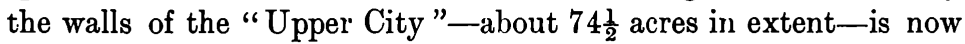
unequally divided by the south wall of the modern town. That portion lying north of the city wall has an area of about $48 \frac{1}{2}$ acres, and, very possibly, its limits may be those of the Roman "Camp." It is quite conceivable that the engineers utilised the north, east, and west walls of the "Upper City," and, to complete the defences, connected the two last by a new wall which followed a line still preserved by the wall of the modern city. ${ }^{4}$ An approximate rectangle, well defended on all sides, and of the regulation size, would thus be formed on the highest part of the hill. ${ }^{5}$ According

1 B.J., vi, 8, 1.

? Ibid., vi, 8, 4.

${ }^{3}$ For information with regard to existing Legionary fortresses, and for many valuable suggestions as to the manner in which the Romans would probably set about the formation of their "Camp" at Jerusalem, I am much indebted to Mr. F. Haverfield.

+ There has never been uny satisfactory explanation of the origin of the south wall of Jerusalem which, for no ostensible reason, excludes a quarter that must have been one of the pleasantest in the ancient city. The true solution of the problem seems to be that the "Camp" existed as a military station long after the reign of Hadrian; and that, eventually, when the garrison of Jerusalem was nominal, and the "Camp" was no longer required, its south wall becsme the southern limit of the city.

5 I was formerly of opinion that the limits of the "Upper City" were those of the "Camp," but I have abandoned this view in consequence of the strong evidence that the normal area of a Legionary fortress did not vary greatly from 50 acres, and the fact that the area of the "Upper City" was as much as $74 \frac{1}{2}$ acres. 
to this view "the Camp" extended, approximately, from David Street to the south wall, and from the west wall to the conduit from "Solomon's Pools."

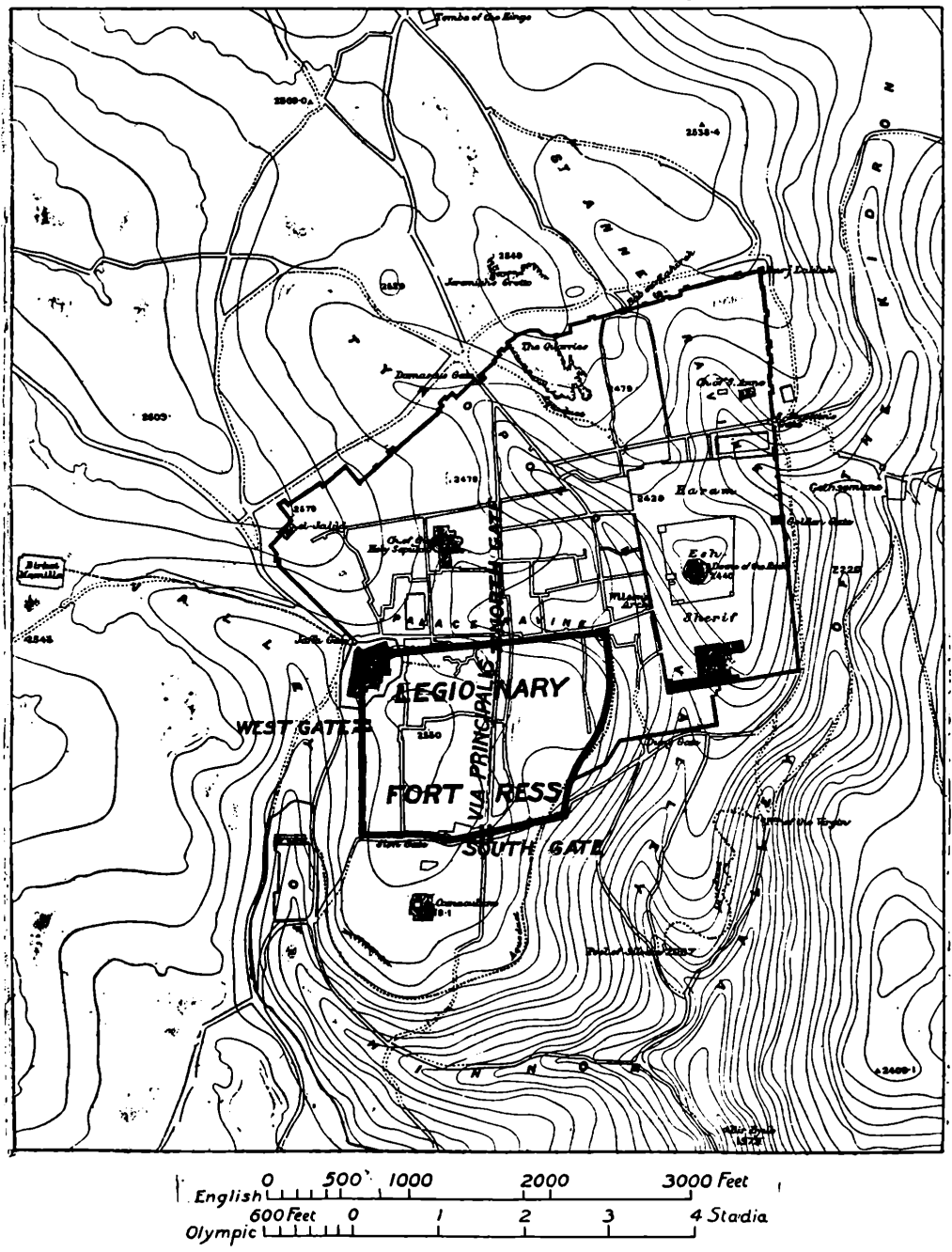

Cajip of the Texth Legion at Jerosalem.

The fortifications not utilised in the construction of "the Camp" were demolished, and on the south the demolition appears to have been 
complete. ${ }^{1}$ How far this was the case on the north is unknown, but it is reasonable to suppose that those portions of the second and third walls in the immediate vicinity of "the Camp" were overthrown, and that the ground was levelled over their ruins. The Roman engineers would not have neglected such an obvious military precaution, and have left cover for a possible enemy in close proximity to their defences. Inside "the Camp," the principal street of the ancient city, the line of which is still preserved, no doubt became the Via principalis with its Northern Gate near the south-east corner of the Muristan, and its Southern Gate at the spot where the Zion Gate stood before the walls were rebuilt by Sultan Suleiman. The West Gate was, probably, at or near the gate in the west wall mentioned by Mukaddasi, A.D. $985,{ }^{2}$ but no trace remains of this gate or of the street which must have led eastward from it. Possibly the Armenian gardens on the west, and the waste ground on the south 3 represent on those sides, the clear spaces that were always left between the walls and the quarters of the soldiers.

Outside "the Camp" Roman and foreign merchants, and those Jews who had taken no part in war, would settle down amidst the ruins of the ancient city for the purposes of trade. These squatters probably rebuilt the old bazârs that lay between the first and second walls ${ }^{4}$; and those of them who were not Jews may have erected a small temple or shrine of Astarte on a site so convenient to the bazârs as that now occupied by the Church of the Holy Sepulchre. Whether any canabce grew up to the south of "the Camp" is uncertain, but it is pleasant to think that Christian fanilies may have settled down in this locality after their return from Pella, and that they may have founded "the mother church of Zion " on the ruins of the house in which Christ had partaken of

1 See the description of the state of the old walls by Dr. Bliss (Bliss and Dickie, Excavations at Jerusalem, 1894-97 ; P.E.F., 1898).

2 Guy le Strange, Palestine under the Moslems, pp. 214-217. The gate was called $B \hat{a} b$ et-Tîh.

3 During the last 50 years most of this ground has been taken up for building.

4 This appears to hare been the belief at the commencement of the twelfth century, for Saewulf writes that the Church of the Holy Sepulchre was " situated on the declivity of Mount Sion, as was the city itself ; after that the Roman princes, Titus and Vespasian, had by the vengeance of the Lord destroyed from the foundations the whole city of Jerusalem" (English translation in the publications of the Palestine Pilgrims' Text Society, pp. 9, 10). 
the Last Supper with His disciples. Within the walls of the Legionary fortress there could have been no church, synagogue, or temple.

2. The Walls of AElia Capitolina.-During the revolt of the Jews in the reign of Hadrian "the Camp" and the suburbs in its vicinity were taken by the insurgents, and recaptured by the Romans. How far they suffered in the prolonged struggle it is impossible to say; but it is reasonable to suppose that, whilst the canabce may have been destroyed, the strong walls of the Legionary fortress were not seriously injured.

When Hadrian was able to carry out his project of rebuilding Jerusalem as a heathen city, one of the first steps that he would take would be to reoccupy "the Camp" with Legionary troops, and restore its walls where they had been breached. The presence of a large Roman garrison in the "Upper City" of Josephus, is indicated by several centurial inscriptions on the tubes of the stone syphon of the "High Level Aqueduct." 1 This aqueduct, is the only one capable of delivering a steady stream of water at the level of "the Camp," and its preservation in a thorough state of repair would be a matter of special importance to the garrison. The Legionary fortress, as elsewhere, would be quite distinct from the civil town which Hadrian made a Colonia. Its walls would long remain, and, on the north and south sides, they appear to have lasted to the reign of Constantine. ${ }^{2}$ The interval which separated the fortress from the "Colony" would coincide very nearly with "David Street." A passage in the Annals of Eutychius, to which M. Clermont-Ganneau has called attention, ${ }^{3}$ appears to contain an allusion to the northern face of the Legionary fortress as restored by Hadrian :- “'The Greeks established themselves there (in Elia) and constructed a fortress at the gate of the Temple called

1 The aqueduct may have been constructed by Herod the Great when he built his fortified palace in the "Upper City" (B.J., v. 4, § 4), or it may have been a Roman military work carried out by the garrison after the capture of the city by Titus. The inscriptions give no certain date. For a discussion of these points, see Quarterly Statement, 1905, pp. 75-77.

2 The Bordeaux Yilgrim, A.D. 333, found the house of Caiaphas outside, and David's Palace, i.e., "David's Tower," inside "the wall of Sion"; and, going northwards to the Gate of Neapolis, i.e., the Damascus Gate, he went "out of the wall of Sion" (Itin. Hierosol). These walls correspond to the north and south walls of the fortress.

${ }^{3}$ Rec. d'Arch. Orientale, rol. vi, pp. 279 sqq. 
ol-Behi $\imath^{1} . .$. This fortress exists to-day at the gate of Jerusalem, and is called the Mihrâb of David." 2

No early writer describes the walls built by Hadrian to protect the civil city, Elia Capitolina, and there is no record of any reconstruction or extension earlier than the fifth century. ${ }^{3}$ It may be inferred from this absence of information that the walls of Constantine's city were the walls of Elia, and that on the north, at least, these walls are represented, conventionally, on the plan of Jerusalem in the Madeba mosaic. It is conceivable that Hadrian built his wall nearly on the line of the third wall of the ancient city; and this view derives some support from the Madeba mosaic and from the Itinerary of the Bordeaux Pilgrim. In the former, city gates are clearly shown in positions that are approximately those of the present Jaffa, Damascus, and St. Stephen Gates. From the Itinerary it would appear that the Birket Isrâil, the pool near the Church of St. Anne, and the twin pools near the Convent of the Sisters of Zion, were within the walls in A.D. 333. ${ }^{4}$ The wall of Elia appears, in fact, to have followed the course of the present wall except, perhaps, near the Jaffa Gate, where it seems to have been drawn in so as to give "David's Tower," and the citadel a clear front.

Some interesting suggestions with regard to the public buildings of Alia, mentioned in the Paschal Chronicle have recently been made by Father Germer-Durand. ${ }^{5}$ The learned Augustinian identifies the Trikameron ${ }^{6}$ with the temple of Jupiter Capitolinus and its three cellce, and considers the Kodrce, that is "Quadra," to be the great quadrangular enclosure, Haram esh-Sherif. in which the Trikameron stood. $\mathrm{He}$ sees in the two demosic municipal buildings connected with the administration of the city,

1 The gate $e l-B e h a \hat{a}$ " the Gate of Beauty," is apparently the present Bâb es-Silsileh, the "Golden Gate" of the Middle Ages.

2 This seems to indicate the citadel at the Jaffa Gate.

3 " The site of the city is almost circular, enclosed within a circuit of walls of no small extent, whereby it now receires within itself Mount Sion, which was once outside" (Eucherius, Epit., Palestine Pilgrim Text Socie ty Series vol. ii). This enclosure of Mount Sion took place before Eudocia (A.D. 449-460) built the wall that included the Pool of Siloam.

+ Itin. Hierosol.

'Echos d'Orient, 1904, pp. 65-71; see also R.B., 1, pp. 369-387.

6 The Trikameron would more naturally be a building with three vaulted rooms like the Basilica of Maxentius at Rome; but the identification proposed above is quite possible. 
and in the T'etranymphon, a bath with four porticos-possibly the Pool of Siloam, which, according to the Bordeaux Pilgrim, ${ }^{1}$ was quadriporticus. The Dodekapylon he regards as the double colonnade of the principal thoroughfare divided by three tetrapylons, and its: name, "the steps," he explains by the steps in the street. But in this last case an identification with some part of the fortifications, or with some great work connected with the approach from the civil city to the temple of Jupiter ${ }^{2}$ would seem preferable.

\section{THE CRYPTS IN ST. ANNE'S CHURCH, JERUSALEM.}

\section{By R. A. Stewart Macalister, M.A., F.S.A.}

At the request of the Rev. Père Cré, of the Monastery of St. Anne, I have examined and measured the crypts found under the ancient Church of St. Anne, and submit herewith a report upon them. Let me say at the outset that I do not share the doubts that have in some quarters been thrown upon their nature, as true relics of antiquity. There can be no question that they are genuinely ancient, and in some respects unique.

A brief notice of the discovery was inserted in the Quarterly Statement for April, 1904, p. 99, and there simultaneously appeared in the Revue Biblique an exhaustive account of the chambers, illustrated with plans and sections, some of them coloured, from the pen of Père Vincent, of the Dominican Biblical School of Saint-Etienne. in Jerusalem. This occupies pp. 228-241 of that journal.

The fulness of this description makes it unnecessary for me to give more than an outline account, sufficient to enable readers of the Quarterly Statement to form a fair conception of the exact nature of the discovery.

The Church of St. Anne, turned after the expulsion of the Crusaders from Jerusalem into a Moslem school and afterwards allowed to fall into decay, was, as is well known, offered first to.

1 Itin. Hierosol.

2 The approach appears to have been by a riaduct, perhaps reached by steps, at “Wilson's Arch." The Dodekapylon may refer to the columns in front of the temple of Jupiter, and the steps that led up to the platform upors which they stood. 